\title{
Yrittäjän sosiaalisen oppimisen motiivit viljanviljelytiloilla
}

\author{
Tiina Vihtonen ${ }^{1)}$ Terri Kupiainen ${ }^{2)}$ \\ ${ }^{1}$ MTT taloustutkimus, Luutnantintie 13,00410 Helsinki, tiina.vihtonen@mtt.fi \\ ${ }^{2}$ MTT taloustutkimus, Luutnantintie 13,00410 Helsinki,terri.kupiainen@mtt.fi
}

\section{Johdanto}

Tässä tutkimuksessa käsitellään yrittäjän oppimista ja opitun soveltamiseen liittyviä kysymyksiä sellaisessa tapauksessa, jossa kehittäminen kohdistuu julkisenvallan politiikan määrittelemien tavoitteiden läpiviemiseen yritystasolla. Julkishallinnon elinkeinopolitiikan ja yritysten kilpailuedun välistä yhteyttä on usein käsitteellistetty Porterin (1980) toimialan kilpailuteorian avulla. Porterin näkemysten mukaisesti oletetaan, että yritysten väliset erot selittävät pysyvien kilpailuetujen muodostumista suhteessa kilpailijoihin. Lisäksi otaksutaan että harjoitetut politiikat edistävät kilpailuetujen muodostumista hyvin samantapaisin mekanismein sekä mikro- että makrotalouden tasolla (Shaffer 1995). Shaffer viittaa mm. Leonen $(1991 ; 1986)$ tutkimuksiin, joissa on havaittu, että julkisen vallan toimenpiteiden vaikutukset synnyttävät yritysten välisiä eroja sekä toimialoilla että toimialojen välillä ja ne tarjoavat mahdollisuuksia kilpailuedun kehittymiselle, mutta eri tyyppiset yritykset hyötyvät sääntelystä eri tavalla, koska muun muassa toimenpiteiden aiheuttamat kustannusvaikutukset eivät ole samanlaisia kaikissa yrityksissä. Tavallinen seuraus on, että yritykset yrittävät kiertää säädöksiä, jos ne aiheuttavat kustannuksia ja saattavat osan yrityksistä epäedulliseen asemaan kilpailijoihin verrattuna. Shaffer (1995) on todennut, että harjoitetun politiikan ja sääntelyn epäsuorat ja tahattomat vaikutukset tunnetaan huonosti. Yleisesti näyttää siltä, että sääntelyn aiheuttamat toimintatapamuutokset nostavat koko toimialan toiminnan tasoa tai muuttavat sitä, mutta yritystasolla sääntely ei enää yksiselitteisesti vaikuta kilpailuetua lisäävästi, koska sen vaikutukset kohdistuvat erilaisina eri yrityksiin. Pahimmassa tapauksessa tuloksena on, että harjoitetusta politiikasta muodostuu helposti vain uusi päätöksentekoon vaikuttava parametri yrityksille.

Talouspolitiikan interventioina elintarvikealan pk-yrittäjille ja maaseutuyrittäjille suunnattua koulutusta ja kehittämistoimintaa on harjoitettu maassamme suhteellisen laajasti erilaisten aluekehittämisen hankkeiden muodossa, jossa koulutuksella on ollut erityinen asema esimerkiksi muihin EUmaihin verrattuna (Bridge ym. 1998). Kehittämistoimintaa koskevan tutkimuksen yhteydessä on usein tarkasteltu myös sitä miten erilaiset kehittämishankkeet tukevat yritysten tuotekehitystä ja markkinointia tai laajemmin koko toimialan menestymistä, alueellista elinkeinoelämää ja työllisyyttä (Dalley \& Hamilton 2000; Johannisson 2000; Mugler 2000). Kuten opettamisessa yleensä, tässäkin yhteydessä on keskusteltu siitä, miten tieto siirtyy koulutuksessa yrityksen omaisuudeksi ja miten yritykset käyttävät ja soveltavat saamaansa tietoa omassa yrityksessään (Storey 2000).

Tämän tutkimuksen tavoitteena on selvittää, miten ja millä ehdoilla tiedosta tulee tarkoituksenmukaista yrittäjille ja miten esimerkiksi laatukoulutuksessa saatu tieto legitimoituu osaksi yritysten johtamista. Laatujärjestelmää tarkastellaan yhteiskunnallisena instituutiona ja laatujärjestelmän omaksumista joko koulutuksessa tai muuten sosiaalisesti motivoituna ja sosiaalisesti välittyneenä oppimisprosessina.

\section{Tutkimuksen teoreettinen lähtökohta}

Sosiaalisen oppimisen teoria yhdistelee osia käyttäytymistieteellisistä ja kognitiivisista oppimisteoriasta. Teoria lähtee siitä, että ihmiset oppivat ensisijaisesti tarkkailemalla muita jossakin sosiaalisessa tilanteessa. Tunnetuimpia tämän koulukunnan edustajista ovat Bandura ja Rotter (Merriam \& Caffarella 1999, 259). Sosiaalisen oppimisen aspekteja on käsitelty myös edellistä laajemmin, jolloin esimerkiksi Dewey'n ja Vygotsky'n tutkimukset on liitetty sosiaalisen oppimisen koulukuntiin (Phillips \& Sottis 1998, 53-64). Sosiaalisen oppimisen käsitteitä ovat mm. sosialisaatio, sosiaaliset roolit ja tiedon sosiaalihistoriallinen välittyminen. Sovellutuksista voidaan mainita esimerkiksi mentorointi. Sosiaalisen tiedonvälittymisen ja oppimisen teorioilla on taloustieteissä viitattu tiedon välittymiseen epävirallisten kanavien kautta esimerkiksi naapurien tai vertaisryhmien välillä ja tiedon adaptoitumiseen tätä kautta (Offerman \& Sonnemans 1998). Opettamisen näkökulmasta sosiaalisen oppimisen teoriat korostavat sosiaalisen ympäristön vaikutusta oppimisen edistämisessä. Kouluttaminen ymmärretään sosiaalisena tilanteena, jossa ihmisillä on taipumus painottaa omia kokemuksiaan ja vastaavasti vähem- 
män muiden antamaa uutta tietoa ja informaatiota. Menestyvien muiden jäljittely vaikuttaa oppimiseen, koska ihmisillä on myös taipumus painottaa omia näkemyksiään muiden näkemysten suuntaan (Offerman \& Sonnemans 1998). Jäljittely parantaa uskomusten laatua ja jäljittelijät ovat keskimäärin menestyvämpiä kuin ne, jotka eivät lainkaan jäljittele muita.

Tämän tutkimuksen oletuksena on, että yrittäjät motivoituvat eri tavoin myös koulutuksessa ja motivaatio vaikuttaa opitun soveltamiseen ja siihen miten koulutus edistää toimintatavan muutosta. Teoreettisena viitekehyksenä on Bergerin ja Luckmannin (1966) teoria tiedon sosiaalisesta rakentumisesta. Teorian mukaan tieto on sosiaalisesti rakentunut tiedon relevanssin, tiedon legitimoitumisprosessien ja institutionalisoitumisen kautta. Tietoprosesseja ovat mm. arkitiedon syntymisen prosessit ja teoreettisen tiedon muodostumisen prosessit. Eri prosesseissa syntynyt tieto on ontologisesti erilaista. Tiedon omaksuminen, sen sisäistäminen ja tiedon käyttö riippuvat siitä, miten kaksi tiedontuottamisen tapaa integroituvat ja toimivat vuorovaikutuksessa toistensa kanssa. Usein teoreettisen tiedon instituutiot (teoreettinen koulutus) ja käytännön yritysmaailma arkitiedon varastona eivät kohtaa riittävästi, jolloin esimerkiksi yrittäjät kokevat asiantuntijoiden välittämän teoreettisen tiedon hyödyn vähäiseksi yritystoiminnan ja omien päämääriensä kannalta (Dalley \& Hamilton 2000; Sexton ym. 1999). Bergerin ja Luckmannin mukaan kyse on tiedon relevanssin ja sen legitimiteetin ongelmista.

Institutionaalinen teoria yhteiskuntatieteissä käsittelee erilaisten toimintojen, kuten normien ja tapojen kehittymistä instituutioiksi. Institutionaalisen teorian piirissä korostetaan sitä, että yrityksen käyttäytyminen on mukautuvaa, totunnaisuuksiin perustuvaa ja sosiaalisesti määriteltyä. Institutionaalisen teorian näkökulmasta yritys tai muu organisaatio toimii sellaisessa sosiaalisessa viitekehyksessä, jossa normit, arvot ja yleisesti hyväksyttyinä pidetyt oletukset määrittelevät taloudellista toimintaa ja käyttäytymistä. Taloudellisia valintoja eivät rajoita ainoastaan neoklassisen talousteorian teknologiaa, informaatiota ja tulonmuodostusta koskevat periaatteet, vaan myös sosiaalisesti rakentuneet rajoitteet, jotka ovat alkuperältään inhimillisiä tapoja, normeja ja totunnaisuuksia. Jokainen instituutio perustuu sosiaalisesti välittyneeseen "reseptitietoon" eli tietoon, joka määrittää institutionaalisesti hyväksyttävän käyttäytymisen säännöt (Berger ja Luckmann 2000, 79). Tämän tutkimuksen näkökulmasta hyväksyttävät säännöt voidaan määritellä sekä yrityksen että laatujärjestelmäinstituution näkökulmasta tutkimalla sitä miten yrittäjät mieltävät hyväksyttäväksi uudet toimintamallit yrityksen sisällä tai suhteessa esimerkiksi toisiin yrityksiin tai markkinoihin.

Zuckerin mukaan $(1987,444)$ institutionaalisuudella tarkoitetaan organisaation yhteydessä joko sitä, että kysymyksessä on säännön kaltainen sosiaalinen fakta (toiminnan kaava tai sääntö eli tapa toimia). Institutionaalisuus viittaa myös yrityksen organisaatiorakenteisiin sisäistyneisiin tekijöihin, jotka eivät ole erilaisista toimijoista tai tilanteista johtuvia (organisaation muodollinen näkökulma tehdä asioita). Levitt ja March (1988) käsittelivät sitä, miten organisaatiot omaksuvat esimerkiksi erilaisia käytäntöjä. He esittivät kolme klassisen organisaatioiden toiminnan tutkimuksen näkökulmaa. Ensimmäisessä näkökulmassa oletetaan, että organisaation toiminta perustuu rutiineihin ja toimintamalleihin, joiden lainalaisuuksien noudattaminen merkitsee usein enemmän kuin uusien toimintamahdollisuuksien harkinta. Toisen näkökulman mukaan organisaation toiminta on historiasidonnaista, sillä toimintamallit perustuvat menneisyyden kokemuksiin enemmän kuin tulevaisuuden ennakointiin. Kolmas näkökulma perustuu siihen, että organisaatiot ovat sitoutuneita päämääriinsä. Tällöin toiminnan lopputuloksia arvioidaan melko karkealla tasolla suhteessa siihen, mitä alunperin on aiottu saavuttaa. Levitt ja March erottivat oppimisen diffuusiossa kolme prosessityyppiä. Ensimmäisessä prosessityypissä diffuusio lähtee liikkeelle yksittäisestä lähteestä, mikä tarkoittaa esimerkiksi sitä, että valtionhallinto edistää voimakkaasti vaikkapa tietyn laskentakäytännön leviämistä organisaatioihin. Toisessa prosessityypissä uusi käytäntö leviää organisaatioilta toiselle joko ilman välittäviä henkilöitä (esim. konsultti) tai välittävien henkilöiden avulla. Kolmannessa prosessityypissä pieni joukko organisaatioita omaksuu ensin uuden käytännön, minkä jälkeen uusi käytäntö leviää ryhmän ulkopuolelle.

\section{Aineisto ja menetelmä}

Tutkimuksen empiirisenä aineistona on vuonna 2002 Suomen viljantuotantotiloille suunnattu lomaketutkimus, joka lähetettiin 990:1le pinta-alaltaan yli 75 ha:n tilalle. Tutkimukseen vastasi 199 yrittäjää. Lomakkeella selvitettiin mm. yrittäjien koulutukseen liittyviä motivaatioita. Analyysimenetelmänä käytettiin faktorianalyysiä (maximum-likelihood) ja ryhmittelyanalyysiä. Ryhmien vertailussa käytettiin yksisuuntaista varianssianalyysiä.

Sosiaalisen oppimisen motiiveina on tarkasteltu verkostoihin liittymisen motiiveita ja oppimisen motiiveita sekä laatujärjestelmän ja laatukoulutuksen hyödyttävyyttä ja koulutuksessa välitetyn tiedon 
koettua relevanssia maatilayrittäjien kannalta. Tässä yhteydessä viitataan mm. Caciappo'n \& Petty'n (1982), Scheinin (1987), Argyrisin (1993) ja Dalley'n \& Hamiltonin (2000) tutkimuksiin, joita on sovellettu operationalisoitaessa tutkimuksen kohteena olevia käsitteitä. Lisäksi mittarin rakentaminen perustuu suurelta osalta omiin aikaisempiin tutkimuksiin ja kokemuksiin.

\section{Tutkimustulokset}

Tutkimuksessa verrattiin miten eritavalla motivoituneet maatilayrittäjät hyötyvät laatukoulutuksesta. Lisäksi verrattiin laatukoulutukseen osallistuneiden $(\mathrm{n}=81)$ oppimismotivaatiota vastaavalla tavalla eilaatukoulutukseen osallistuneiden yrittäjien sosiaalisen oppimisen motiiviin. Analyysissä verkottumista, oppimista sekä laatujärjestelmäkoulutuksen ja laatujärjestelmän hyödyttävyyttä mitanneista muuttujista muodostettiin erillisten faktorianalyysien avulla seitsemän uutta muuttujaa: verkottumiselle kaksi, oppimiselle kolme sekä laatujärjestelmäkoulutukselle ja laatujärjestelmän hyödyttävyydelle kaksi faktoria (taulukko 1).

Taulukko 1. Faktorit, mittareiden luotettavuus ja ryhmävertailun f-testi.

Sosiaalisen oppimisen motivaatiot ja laatujärjestelmäkoulutus

\section{Mittareiden Ryhmäver- \\ lukumäärä tailun \\ Cronbachin F-testi alfa}

Verkottuminen ( $\mathrm{n}=191$,varianssin selitysosuus 58,1\%)

- Suhteet muihin yrittäjiin oppimisen ja ideoiden lähteenä

- Koulutus oppimisen ja ideoiden lähteenä

Oppimismotiivit ( $\mathrm{n}=199$, varianssin selitysosuus 42,7\%)

- Oppimisen autonomia

- Pragmaattisuus ja koulutuksen kritiikki

- Oppiminen tulevaisuutta varten

$\begin{array}{cc}3(\alpha=0,71) & 75,621 \\ 2(\alpha=0,76) & 68,908 \\ & \\ 4(\alpha=0,80) & 68,175 \\ 6(\alpha=0,70) & 5,348 \\ 1(-) & 68,743\end{array}$

Laatujärjestelmäkoulutus ja koettu hyöty $(n=81$, varianssin selitysosuus $67,5 \%$ )

- Laatujärjestelmäkoulutuksen hyöty tuotannon ohjauksessa

- Laatujärjestelmäkoulutuksen hyöty liiketoiminnan ohjauksessa

$\begin{array}{ll}6(\alpha=0,92) & 3,114 \\ 2(\alpha=0,74) & 0,835\end{array}$

Verkottumista ja oppimista mitanneiden uusien muuttujien avulla muodostettiin neljä ryhmää, jotka nimettiin seuraavasti: Autonomiset pragmaattiset verkottujat (24\%), Autonomiset koulutusmyönteiset (36\%), Pragmaattiset verkottujat $(19 \%)$ ja Yksin puurtajat (21\%). Tutkimuksessa havaittiin, että autonomiset pragmaattiset verkottujat ja autonomiset koulutusmyönteiset ovat iältään vanhimpia ja eniten koulutettuja. Vastaavasti Yksin puurtajilla on alhaisin koulutustaso (Kruskallin-Wallisin testi $\mathrm{p}=0,001)$. Nuorimmat yrittäjät ovat oppimisen ja tiedon motivaatioiltaan Yksin puurtajien ryhmässä ja vanhimmat Pragmaattisten verkottujien ryhmässä. Ryhmät eroavat merkitsevästi toisistaan myös oppimismotiiviensa suhteen. Ryhmien nimet kuvaavat yrittäjien oppimisen ja tiedon motivaatioiden perussuuntautuneisuutta. Pragmaattiset verkottujat kokevat muita ryhmiä pienempiä hyötyjä laatukoulutuksesta, mutta ovat oppimiseen motivoituneita ja arvioivat kykenevänsä oppimaan vaikeitakin asioita itsenäisesti vaikka suhtautuvat kriittisesti koulutukseen. He arvioivat yrittäjäverkoston tuottaman tiedon merkitykselliseksi ideoiden lähteeksi. Yksin puurtajat motivoituvat muita vähemmän yrittäjäverkoistoista ja arvioivat saavansa koulutuksesta vähiten ideoita, mutta samalla he kokevat olevansa oppimisen suhteen merkitsevästi vähemmän itsenäisiä kuin muut ryhmät. Yksin puurtajat ovat oppimisessaan muita ryhmiä enemmän tulevaisuuteen suuntautuneita. Kaiken kaikkiaan laatukoulutukseen osallistuneet ovat merkitsevästi muita yrityksiä koulutusmyönteisempiä, hyvin koulutettuja ja jonkin verran vanhempia kuin ne, jotka eivät ole koulutukseen osallistuneet. Kuviosta 1 voidaan päätellä, että yrittäjät ovat kokeneet laatujärjestelmäkoulutuksen hyödyt liiketoiminnan ohjauksessa samanlaisina. Sen sijaan tuotannonohjauksessa Pragmaattiset verkottujat ja Yksin puurtajat kokevat laatujärjestelmäkoulutuksen hyödyt muita ryhmiä merkitsevästi pienempinä. Käytäntöön suuntautunut autonomisuus motivaation lähteenä vähentää koettua hyötyä laatukoulutuksen molempien funktioiden osalta ja koulutusmyönteisyys vastaavasti lisää sitä selvästi. 


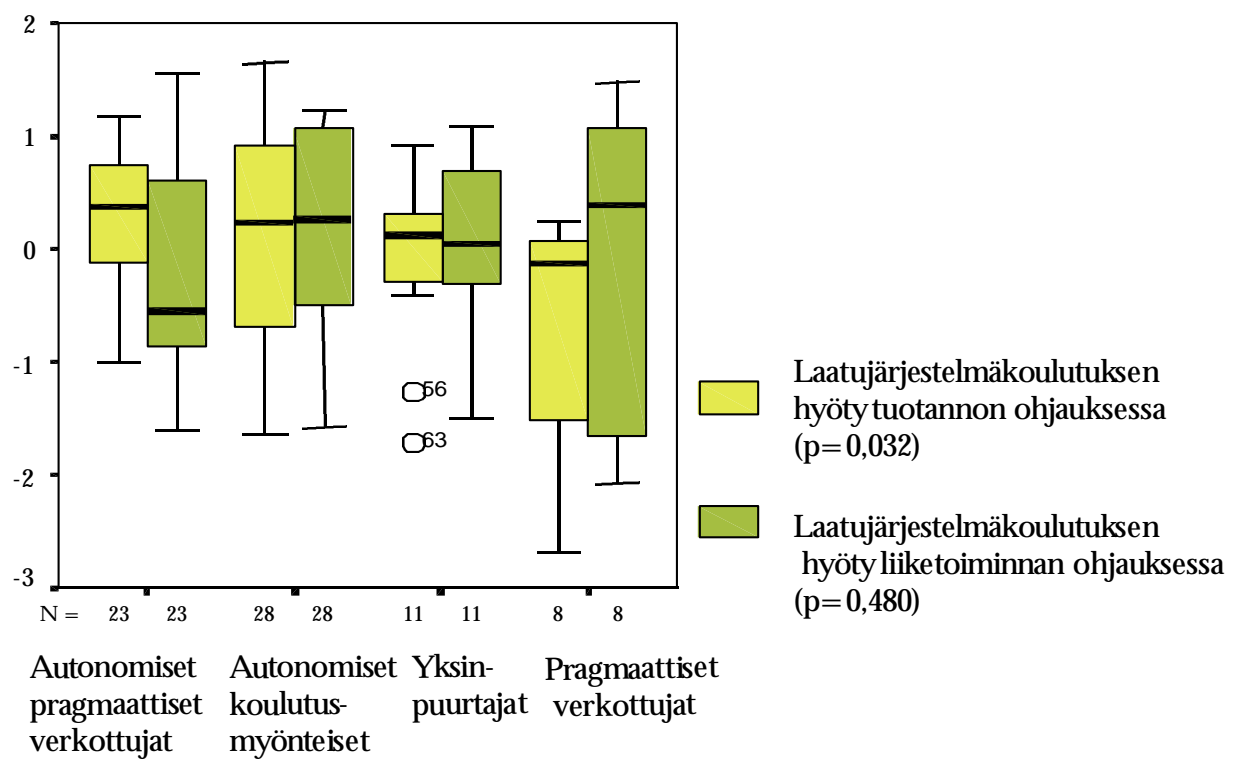

Kuvio 1. Maatilayrittäjien oppimismotivaatiot ja laatujärjestelmäkoulutuksen koettu hyöty tuotannon ja liiketoiminnan ohjauksessa $(n=81)$.

\section{Päätelmät}

Tutkimuksessa on tarkasteltu sitä, miten viljatilayrittäjät omaksuvat tietoa koulutuksessa ja kuinka motivoituneita he ovat tiedon käyttäjinä. Tutkimuksen empiirinen aineisto tukee teoriaa oppimisen institutionaalisesta luonteesta ja sen tuloksia voidaan käyttää koulutuksen ja kehittämistoiminnan suunnittelussa. Erityisesti yrittäjien erilaisten motivaatioiden ja lähtökohtien huomioon ottaminen laatukoulutuksen suunnittelussa ja tuloksien arvioinnissa nousee esille pohdittavana kysymyksenä.

\section{Kirjallisuus}

Argyris, C. 1993. Knowledge for Action. Jossey-Bass Publisher, San Francisco.

Berger, P. L. \& Luckmann, T. 2000. Todellisuuden sosiaalinen rakentuminen. Tiedonsosiologinen tutkielma. Yliopistopaino. Helsinki 2000. $255 \mathrm{~s}$.

Bridge, S., O’Neill, K. \& Cromie, S. 1998. Understanding Enterprise, Entrepreneurship and Small Business. MacMillan, Great Britain.

Caciappo, J. \& Petty, R. 1982. The need for cognition. Journal of Personality and Social Psychology, 42(1):116131.

Dalley, J. \& Hamilton, B. 2000. Knowledge and Learning in Small Business. International Small Business Journal (April-June)3:51-59.

Johannisson, B. 2000. Networking and Entrepreneurial Growth. In Handbook of Entrepreneurship Eds, Sexton, D. \& Landström, H. Blackwell:368-386.

Levitt, B. \& March, J. G. 1988. Organizational Learning. Annual Review of Sociology, Volume 14 (1988):319340.

Merriam, S. \& Caffarella, R. 1999. Adult learning. A Comprehensive guide. Jossey-Bass.

Mugler, J. 2000. The Climate for Entrepreneurship in European Countries in Transition. In Handbook of Entrepreneurship Eds, Sexton, D. \& Landström, H. Blackwell: -150-175

Offerman, T. \& Sonnemans, J: 1998. Learning by experience and learning by imitating sucessfull others. Journal of Economic Behaviour \& Organizartion vol 34: 5549-575.

Phillisps, D. \& Soltis, J. 1998. Perspectives on learning. Teachers Collage Press.

Schein, E. 1987. Process Consultation. Volume II. Lessons for Managers and Consultants. Addison-Wesley Publishing Company.

Shaffer, B. 1995. Firm-level responces to coverment regulations: Theoretical and research approach. Journal of Management, 21, 3: 495-514.

Storey, D. 2000. Six Steps To Heaven: Evaluating the Impact of Public Policies to Support Small Businesses in Developed Economies. In Handbook of Entrepreneurship Eds, Sexton, D. \& Landström, H. Blackwell: 176-193.

Zucker, L. 1987. Institutional Theories of Organization. Annual Review of Sociology. Vol. 13: 443-464. 